\title{
Formação inicial docente e suas relações dentro do âmbito escolar
}

\section{Teachers in Initial training and their relationships in the school context}

\author{
Regiane Stafim da Cunha ${ }^{1}$. Marina Rosa Stec dos Santos ${ }^{2}$. \\ Jaqueline Dittrich ${ }^{3}$. Maiara Vicentini ${ }^{4}$. \\ Liege da Silva Oliveira Stavis ${ }^{2}$. Christiane Gioppo Marques da Cruz ${ }^{5}$
}

\begin{abstract}
Resumo: A formação inicial de professores inclui o estágio em docência, que proporciona a vivência do cotidiano escolar. A partir disso, o presente estudo investiga a experiência de quatro estagiários de professores de Biologia em diferentes turmas de Ensino Médio da Educação Básica. Para tanto, cada estagiário produziu relatos que foram submetidos à análise da ação docente utilizando o instrumento Matriz 3x3 baseado no sistema didático de Chevallard e na gestão das relações com o saber de Charlot, proposto por Arruda, Lima e Passos. O estágio foi marcado pelo uso de diferentes práticas metodológicas, tais como criação e montagem de modelos didáticos, vídeos e gravuras, de forma que os estagiários puderam refletir sobre a prática docente e sobre as relações existentes no âmbito da escola.
\end{abstract}

Palavras-chave: Formação inicial de professores. Prática docente. Estágio. Ensino de biologia. Ensino médio.

\begin{abstract}
Initial training in teaching includes traineeship, providing future teachers the experience of everyday school life. From this, the present study investigates the experience of four biology teacher trainees in different high school classes. Each trainee has produced reports that were submitted to analyze their teaching activities using the $3 \times 3$ Matrix instrument based on Chevallard's didactic system and in the relationships with knowledge management of Charlot, which was proposed by Arruda, Lima and Passos. The teaching practice was marked by the use of different methodological practices, such as creating and mounting didactic models, videos and pictures. Thus, the trainees were able to reflect on the teaching practice and on the relationships within the school.
\end{abstract}

Keywords: Initial teachers training. Teaching practice. Traineeship. Biology teaching. High school.

\footnotetext{
${ }^{1}$ Universidade Federal do Paraná (UFPR), Programa de Pós-graduação em Microbiologia, Parasitologia e Patologia, Curitiba, PR, Brasil. E-mail: <regidacunha@gmail.com>.

${ }^{2}$ Universidade Federal do Paraná (UFPR), Curitiba, PR, Brasil.

${ }^{3}$ Universidade Estadual de Maringá (UEM), Programa de Pós-graduação em Ecologia de Ambientes Aquáticos Continentais, Maringá, PR, Brasil.

${ }^{4}$ Universidade Federal do Paraná (UFPR), Programa de Pós-graduação em Ecologia e Conservação, Curitiba, PR, Brasil.

${ }^{5}$ Universidade Federal do Paraná (UFPR), Departamento de Teoria e Prática de Ensino, Curitiba, PR, Brasil.
} 


\section{Introdução}

A formação inicial docente, promovida pelos cursos universitários de licenciatura no Brasil, requer o reconhecimento dos professores como sujeitos do conhecimento e produtores de saberes (ALMEIDA; BIAJONE, 2007). Esse reconhecimento deve permear tanto sua atuação na Educação Básica quanto o processo de formação desses profissionais, pois os futuros professores serão mediadores do conhecimento, dos saberes em transformação, das culturas e dos valores da sociedade. Perrenoud (1999) considera que os professores devem se reconhecer como depositários da tradição e como precursores do futuro e, por isso, é importante que sejam preparados para uma prática reflexiva, inovadora e cooperativa.

Nesse sentido, a disciplina de estágio em docência, componente curricular obrigatório dos cursos de licenciatura, é essencial para que os futuros docentes sejam expostos a diferentes possibilidades teórico-práticas e que possam, ao longo da experiência, construir sua própria identidade profissional. Ou seja, é necessário que o aluno se veja como professor. Por isso, a organização dessa disciplina deve ser pautada pelo diálogo, pela colaboração, pela troca, pela descoberta e pela reflexão. (GIANOTTO; DINIZ, 2010).

A concepção do professor como prático reflexivo foi inicialmente proposta por Schön (1992). Esse autor ressalta que o professor deve deixar de ser um técnico, cujas ações sejam pautadas por resoluções mecanicistas, para ser um investigador em sala de aula, sendo capaz de problematizar as questões que surgirem, refletir sobre elas e, então, resolvê-las. Este professor prático autônomo será capaz de resolver situações e de manejar a realidade com base na integração entre conhecimento e técnica. Esta integração é adquirida ao longo da prática docente (PÉREZ GÓMEZ, 1992).

Por isso, é essencial que o processo de formação envolva todas as fases da atuação docente e do trabalho dos professores, de maneira que o professor aprendiz consiga refletir sobre a prática de outros professores e, então, construir seu "eu" professor, sua identidade docente. Assim, devem-se levar em conta as diversas relações que o professor aprendiz pode estabelecer ao longo de seu estágio, desde suas relações com os colegas, com os alunos, com o conteúdo, até a relação com os próprios professores, promovendo uma imersão no ambiente escolar, que promova a reflexão crítica.

O estágio docente é o momento proporcionado para os estagiários vivenciarem a teoria na prática, por meio das mais diversas experiências. Dentre as situações possíveis de serem vividas está a de confronto com a realidade. O conhecimento formal do currículo universitário por muitas vezes está distante do que ocorre no cotidiano escolar. Será no âmbito escolar, principalmente na sala de aula, que o estagiário relacionará tudo o que viu na teoria com o que é vivido na prática. Entenderá a escola como um grupo interativo, cheio de imprevistos, descobrindo seus valores, funcionamento e todo o trabalho de seus integrantes, como aborda Lima (2008). Essa mesma autora traz ainda algumas das lições e reflexões que o estágio docente deve proporcionar. Dentre elas estão as que dizem respeito à movimentação dos integrantes da comunidade dentro do ambiente escolar como um todo e como são as relações e essa movimentação dentro da própria sala de aula.

Sobre essas relações interpessoais em sala de aula, Rosa e Veit (2011) afirmam que muitas vezes o que se é planejado fracassa em decorrência da falta de capacidade do estagiário em conter situações de indisciplina e violência. Alunos são seres inconstantes e diferentes entre 
si. Eles são “uma realidade em constante movimento" (MORASSUTI et al., 2008). Portanto, uma turma não estará com o mesmo comportamento sempre que o estagiário entrar em sala. Dessa maneira, muitas relações podem ocorrer dentro desse ambiente.

Para auxiliar nesse processo de compreender e permanecer em uma sala de aula como estagiário docente, é essencial a presença de um professor responsável da própria escola. Muitas vezes o estagiário não está preparado ou não obteve conhecimentos suficientes durante a carreira acadêmica para passar por determinadas situações. Da mesma maneira que nem sempre o professor orientador da universidade teve muito contato com o ambiente escolar, portanto não conhece a realidade desse sistema de ensino. Assim, o professor da escola pode contribuir com reflexões e experiências adquiridas durante sua carreira, bem como detectar os problemas e lacunas na formação de docente (LÜDKE, 2009).

Além dessas relações com a realidade escolar, a sala de aula e o professor, os estagiários também podem manter contato com a equipe pedagógica e a da escola. Dentre as atividades do coordenador pedagógico está a identificação de necessidades dos professores, bem como a busca por suas soluções e a articulação dos componentes escolares (MENEZES, 2012). Assim, quando o estagiário assumir a docência como professor formado, ele estará sempre em contato com esta equipe, portanto deve começar essa relação já durante o período de estágio. O mesmo ocorre com relação à diretoria da escola, uma vez que estes são os grandes articuladores da instituição de ensino.

Com base nos tópicos abordados, o objetivo do presente artigo foi analisar relatos de experiência de quatro estagiários docentes, em diferentes turmas do Ensino Médio, com foco na questão de conteúdo aplicado e em todas as relações presentes no âmbito escolar.

\section{A ação docente por meio do instrumento Matriz 3x3}

A ação docente em sala de aula compreende as relações que ocorrem nesse ambiente bem como a gestão delas. Sobre esse aspecto, a relação com o saber pode ter três dimensões: a epistêmica, a pessoal e a social de acordo com Charlot (2000), adaptado por Arruda, Lima e Passos (2011). Sendo assim, a relação epistêmica compreende o saber como objeto do mundo que pode ser apropriado e compreendido pelo sujeito. Já a relação pessoal trata o saber como objeto de desejo e interesse do sujeito, no qual se evidencia a identidade com o saber. Por fim, a relação social associa o saber com o objeto social, cujo qual tem valores atribuídos pela sociedade e, portanto, é influenciado pelas expectativas dos outros sobre ele.

As relações com o saber no contexto da sala de aula podem ser vinculadas com o sistema didático proposto por Chevallard (2005). Esse sistema é formado por três segmentos decorrentes das relações entre o professor e o saber (P-S), entre o professor e o estudante (P-E) e ainda entre o estudante e o saber (E-S) que correspondem, respectivamente, ao saber a ser ensinado (conteúdo disciplinar), à prática de ensino e ao processo de aprendizagem.

Com base tanto no sistema didático de Chevallard (2005) como na gestão das relações com o saber de Charlot (2000), Arruda, Lima e Passos (2011) propuseram um instrumento de análise da ação docente denominado Matriz 3x3 (Quadro 1) com o escopo de investigar os diversos aspectos da ação docente. 
Quadro 1. Matriz 3x3 para a análise da ação docente

\begin{tabular}{|c|c|c|c|}
\hline $\begin{array}{l}\text { Tarefas } \\
\text { Relações } \\
\text { de saber }\end{array}$ & $\begin{array}{c}1 \text { Gestão do } \\
\text { segmento } \\
\text { P-S (conteúdo) }\end{array}$ & $\begin{array}{l}2 \text { Gestão do } \\
\text { segmento } \\
\text { P-E (ensino) }\end{array}$ & $\begin{array}{c}3 \text { Gestão do } \\
\text { segmento } \\
\text { E-S (aprendizagem) }\end{array}$ \\
\hline A: Epistêmica & $\begin{array}{l}\text { Setor 1A: } \\
\text { Conteúdo enquanto } \\
\text { objeto a ser } \\
\text { compreendido pelo } \\
\text { professor. }\end{array}$ & $\begin{array}{l}\text { Setor 2A: } \\
\text { Ensino enquanto } \\
\text { atividade a ser } \\
\text { compreendida pelo } \\
\text { professor. }\end{array}$ & $\begin{array}{l}\text { Setor 3A: } \\
\text { Aprendizagem } \\
\text { enquanto atividade a } \\
\text { ser compreendida pelo } \\
\text { professor. }\end{array}$ \\
\hline B: Pessoal & $\begin{array}{l}\text { Setor 1B: } \\
\text { Conteúdo enquanto } \\
\text { objeto pessoal. }\end{array}$ & $\begin{array}{l}\text { Setor 2B: } \\
\text { Ensino enquanto } \\
\text { atividade pessoal. }\end{array}$ & $\begin{array}{l}\text { Setor 3B: } \\
\text { Aprendizagem enquanto } \\
\text { atividade pessoal. }\end{array}$ \\
\hline C: Social & $\begin{array}{l}\text { Setor 1C: } \\
\text { Conteúdo enquanto } \\
\text { objeto social. }\end{array}$ & $\begin{array}{l}\text { Setor } 2 \mathrm{C} \text { : } \\
\text { Ensino enquanto } \\
\text { atividade social. }\end{array}$ & $\begin{array}{l}\text { Setor } 3 \mathrm{C}: \\
\text { Aprendizagem enquanto } \\
\text { atividade social. }\end{array}$ \\
\hline
\end{tabular}

Fonte: Arruda, Lima e Passos (2011, p. 147).

\section{Procedimentos metodológicos}

O estágio de prática em docência foi realizado em duas escolas de Ensino Fundamental e Médio na região de Curitiba, Paraná. Os quatro estagiários do curso de Ciências Biológicas acompanharam turmas do Ensino Médio durante todo o segundo semestre de 2014, sendo que três realizaram o estágio em um colégio do bairro Capão da Imbuia e o outro no colégio do bairro Cajuru. Foram acompanhadas turmas de $1^{\circ}$ e $3^{\circ}$ ano de Ensino Médio Regular e turmas do $2^{\circ}$ e $3^{\circ}$ ano de Ensino Técnico Profissionalizante em Informática. Cada estagiário ficou responsável por desenvolver suas atividades em uma turma.

O estágio foi realizado com o acompanhamento de duas a quatro aulas semanais e as atividades desenvolvidas contaram com a observação de aulas, auxílio ao professor supervisor e docência. Cada estagiário ministrou em torno de quatro a oito aulas. Ao final do semestre os estagiários relataram algumas de suas experiências e reflexões de forma livre em um pequeno texto. Tal relato foi então submetido à análise conforme a Matriz 3x3 proposta por Arruda, Lima e Passos (2011). 


\section{Análise de dados e reflexão da experiência docente}

\section{Aplicação da Matriz 3x3 e as relações no meio escolar}

A seguir constam os relatos elaborados pelos estagiários identificados como sujeitos A, B, C e D (Quadro 2). Os dados analisados de acordo com a Matriz 3x3 são apresentados no Quadro 3.

Os dados mostram que se obteve uma reflexão dos estagiários nas dimensões da relação epistêmica, pessoal e social no que concerne a cada segmento, discutindo sobre o conteúdo, o ensino e o aprendizado. Esses elementos são essenciais na prática docente e estão presentes no cotidiano da escola.

No segmento P-S, nota-se como o livro didático é importante para o planejamento das aulas, porém outras fontes também são exploradas na relação epistêmica com o conteúdo. As falas da relação pessoal destacam a necessidade de utilizar diferentes práticas metodológicas nas aulas assim como contextualizar o conteúdo. Além disso, a experiência compartilhada com os demais professores da escola é importante para os estagiários na relação social com o saber.

O segmento P-E mostrou as perspectivas dos estagiários sobre o ensino. Sobre a relação epistêmica com o ensino, os estagiários procuraram trabalhar com experimentos e utilizar diferentes recursos didáticos nas aulas, dentre os quais eles mesmos criaram e construíram dois modelos didáticos. Já do ponto de vista da relação pessoal, a experiência com o ensino foi interessante ao mesmo tempo em que foi um desafio vivenciado por cada estagiário na turma que acompanhou ao longo do semestre. Também ficou perceptível que as interações entre os sujeitos na sala de aula estão suscetíveis a oscilações que influenciam o convívio social.

O processo de aprendizagem, tratado no segmento E-S, foi abordado diversas vezes nas falas dos estagiários. Dessa forma, são destacadas na relação epistêmica as dificuldades dos alunos quanto à compreensão e interpretação de textos trazidos pelo professor ou pelo estagiário. A percepção pessoal dos estagiários quanto à dificuldade dos alunos refletiu em buscar formas diferentes em ensinar, usar recursos didáticos, trazer temas atuais e até mesmo pedir para os alunos refletirem. A relação social com a aprendizagem se destacou quanto aos hábitos dos alunos e também ao engajamento em determinadas atividades escolares.

A partir da caracterização das falas, foi possível verificar as maiores preocupações dos estagiários durante a sua ação docente. Com isso, observa-se uma concentração dessas falas na gestão do segmento E-S, especialmente quanto às relações epistêmicas e pessoais, indicando uma preocupação com o processo de aprendizagem. Não só isso como também a relação pessoal no segmento P-E se destacou. Sobre este aspecto, nota-se que a experiência pessoal na docência é marcante para os estagiários. Maistro (2012) ao investigar as perspectivas dos acadêmicos do curso de Ciências Biológicas sobre a docência por meio da Matriz 3x3 mostrou que os relatos desses estudantes se concentraram no segmento P-E, aspecto pelo qual o estágio proporcionou um avanço quanto à experiência docente.

Utilizando o mesmo método na pesquisa com estudantes em formação inicial docente em Física, Fejolo (2013) afirma que o instrumento serviu como fundamento teórico interpretativo para identificar as relações com o saber. Em sua pesquisa, o autor verificou uma preocupação acentuada dos estagiários com o processo de ensino. Piratelo, Carvalho e Arruda (2012) também aplicaram a Matriz 3x3 para avaliar as reflexões sobre a docência de estudantes 
Quadro 2. Relatos dos estagiários sobre a prática docente no ensino médio

\begin{tabular}{|c|c|}
\hline Estagiário & Relato sobre a prática docente \\
\hline Sujeito A & 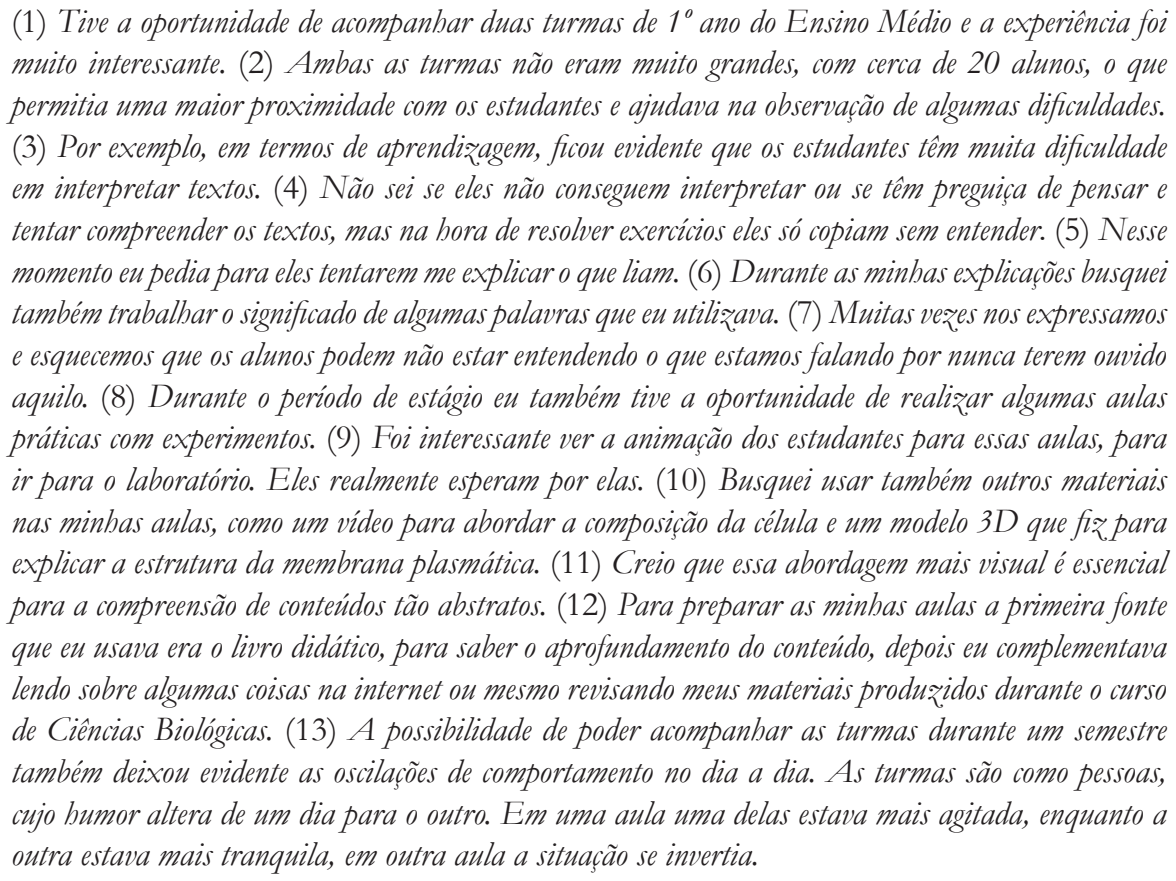 \\
\hline Sujeito B & $\begin{array}{l}\text { (14) Neste semestre, acompanbei uma turma de } 3^{\circ} \text { ano do Ensino Médio, na modalidade bloco. Foi } \\
\text { uma experiência muito interessante e diferente, visto que só tinha trabalhado até então com o Ensino } \\
\text { Fundamental. (15) Talvezpor ser no turno da tarde, a turma era bem pequena, com cerca de quinze } \\
\text { alunos, sendo que um desistiu durante o percurso. (16) Sabe-se que o conteúdo do Ensino Médio é } \\
\text { mais denso, e exige mais atenção. (17) Eu, por exemplo, ministrei aulas de Ciclos Biogeoquímicos e } \\
\text { Genética, e, mesmo pedindo atenção máxima dos alunos, eles não conseguiam focar nas aulas. (18) } \\
\text { Percebi que eles têm uma dificuldade enorme em atingir esse foco e em ler e compreender o que se pede, } \\
\text { até mesmo em aulas um pouco mais dinâmicas. (19) Prova disso foi uma aluna que disse, durante um } \\
\text { atendimento individual para a recuperação no último dia de aula, que era muito mais fácil quando ela } \\
\text { lia o exercício com calma e tirava dele todas as informaçôes. Eles mesmos reconhecem suas dificuldades. } \\
\text { (20) Além dessas relaçôes dentro da sala de aula, a permanência na sala dos professores também foi } \\
\text { de grande importância. (21) Permanecer lá durante o tempo que não havia aula possibilitou troca de } \\
\text { experiência com outros professores, enriquecendo ainda mais o estágio em docência. }\end{array}$ \\
\hline
\end{tabular}

da Física durante o Estágio Supervisionado. Estes autores encontraram uma maior preocupação dos estudantes com as relações epistêmicas e em relação à aprendizagem dos alunos. Já Carvalho, Arruda e Passos (2013) utilizaram o aporte teórico das relações com o saber e do sistema didático para investigar a maneira pelo qual o professor supervisor orienta os licenciandos de 
Quadro 2. continuação

\begin{tabular}{|c|c|}
\hline Estagiário & Relato sobre a prática docente \\
\hline Sujeito C & $\begin{array}{l}\text { (22) A experiência do estágio favoreceu a minha aproximação com a prática docente e com a realidade } \\
\text { escolar. (23) Ao longo desse semestre, pude acompanhar e ministrar aulas de Biologia para uma turma } \\
\text { de Ensino Técnico de Informática integrado com o Ensino Médio. (24) Uma das principais diferenças } \\
\text { em atuar no Ensino Técnico foi a menor carga horária de Biologia que eles possuem em comparação } \\
\text { com o Ensino Médio Regular. (25) Com isso, priorizou-se tratar os assuntos da melhor forma possível, } \\
\text { procurando não o fazer apressadamente. (26) Percebi uma relutância da turma no início com o tema de } \\
\text { Genética, porém com o passar das aulas houve um consentimento. (27) O tema é considerado por muitos } \\
\text { de difícil compreensão, mas é interessante quando contextualizado. (28) Assim, fiz um modelo para } \\
\text { representar as ervilhas de Mendel no ensino da Primeira Lei. (29) Também foi possivel observar que, } \\
\text { por vezes, os alunos querem a resposta pronta ao invés de desenvolvê-la. (30) Diante disso, foi necessário } \\
\text { repetir, retomar e explicar de forma diferente. (31) Para muitos alunos, parece que ser apenas aprovado } \\
\text { com a nota necessária já é bom o bastante, recusando em participar de atividades que não 'valessem } \\
\text { nota'. (32) Eu também tive a oportunidade de acompanhar e participar da construção de uma 'sala } \\
\text { ao ar livre', de iniciativa de vários professores da escola e com o envolvimento dos alunos. (33) Sobre } \\
\text { isso, foi muito interessante ver o engajamento nesse projeto, especialmente por parte dos alunos. (34) } \\
\text { Particularmente, entrar na sala de aula como professora foi um desafio, no qual todo o planejamento } \\
\text { está à mercê de diversos fatores que podem alterá-lo. }\end{array}$ \\
\hline Sujeito D & $\begin{array}{l}\text { (35) Durante o estágio de prática de docência, acompanhei uma turma de segundo ano do Ensino Médio } \\
\text { técnico em Informática. (36) O que mais me chamou atenção ao longo do semestre foi a dificuldade el } \\
\text { ou preguiça que eles tem em efetivamente estudar em casa. (37) Ou seja, de uma aula para outra, eles } \\
\text { pouco lembravam do que foi passado anteriormente, independentemente de quantas vezes o conteúdo foi } \\
\text { abordado ou enfatizado em sala. (38) Além disso, costumavam realizar provas sem estudo prévio; isso } \\
\text { era evidente porque as questões referiam-se a conteúdos presentes no livro e eram respondidas muitas } \\
\text { vezes de forma errada, ou fora de contexto. (39) Isso evidencia a perda do hábito de leitura por parte } \\
\text { desses alunos, seja do livro didático ou de informações do dia-a-dia, presentes em jornais ou na Internet. } \\
\text { (40) Quando foram trabalhados temas atuais em sala de aula, como Biotecnologia, houve grande } \\
\text { participação dos estudantes, visto que utilizamos desenhos explicativos no quadro e uma atividade que } \\
\text { envolveu a exibição de vídeos sobre organismos geneticamente modificados, associada a um questionário } \\
\text { sobre os mesmos. (41) A exibição dos vídeos envolveu muito os alunos, que participaram da aula e } \\
\text { efetivamente responderam as questões propostas. (42) Esses fatos me fazem pensar sobre o método de } \\
\text { ensino, se a aula expositiva é realmente efetiva. (43) A exposição do conteúdo sempre se faz necessária, } \\
\text { mas deve ser associada a outras práticas metodológicas, para que os alunos sejam de fato envolvidos no } \\
\text { tema abordado, principalmente quando se trata da disciplina de Biologia. }\end{array}$ \\
\hline
\end{tabular}

Fonte: elaborado pelos autores.

Física no ambiente escolar, mostrando que a experiência do próprio professor supervisor é determinante na sua orientação.

Durante o estágio, além das diversas relações com conteúdo e metodologia, os estagiários também têm a oportunidade de conhecer mais sobre a escola e se relacionar com os diferentes setores da mesma. Um dos estagiários comentou sobre a troca de experiências dentro da sala dos professores. Souza et al. (2005) ressaltam a importância do planejamento coletivo no 
Quadro 3. Caracterização das falas dos estudantes da prática de docência

\begin{tabular}{|c|c|c|c|}
\hline Todos os sujeitos & $\begin{array}{c}\text { 1: } \\
\text { Gestão do segmento } \\
\text { Professor-Saber (P-S) }\end{array}$ & $\begin{array}{c}2: \\
\text { Gestão do segmento } \\
\text { Professor-Estudante (P-E) }\end{array}$ & \begin{tabular}{|c} 
3: \\
Gestão do segmento \\
Estudante-Saber (E-S)
\end{tabular} \\
\hline $\begin{array}{c}\text { A: } \\
\text { Relação epistêmica }\end{array}$ & (12) & (8), (10), (11), (25), (28) & $\begin{array}{l}\text { (2), (3), (4), (7), (9), (15), } \\
(17),(18),(19),(29),(36)\end{array}$ \\
\hline $\begin{array}{c}\text { B: } \\
\text { Relação pessoal }\end{array}$ & (16), (27), (42), (43) & $\begin{array}{c}(1),(6),(14),(22),(23),(24), \\
(34),(35)\end{array}$ & $\begin{array}{c}\text { (5), (26), (30), (31), (37), } \\
\text { (38), (40), (41) }\end{array}$ \\
\hline $\begin{array}{c}\text { C: } \\
\text { Relação social }\end{array}$ & $(20),(21),(32)$ & (13) & (33), (39) \\
\hline
\end{tabular}

Fonte: elaborado pelos autores.

trabalho pedagógico. Assim, professores e pedagogos devem trabalhar em conjunto, entrando em consenso e elaborando propostas pedagógicas que sejam eficientes. Marcelos (2009) afirma que a escola é um sistema composto por grupos diferentes que interagem entre si de forma sincrônica. Dessa forma, o estagiário deve permear por todos os ambientes escolares para sentir como essas interações devem ocorrer e sua importância para a escola.

\section{Metodologias complementares}

A utilização e produção de materiais diferenciados para o ensino de determinados conteúdos foi relatado por três dos quatro estagiários. A utilização de vídeos disponíveis na internet e produção de modelos tridimensionais atuaram no auxílio ao ensino de conteúdos considerados mais abstratos ou de difícil compreensão, como Biologia Celular, Genética e Biotecnologia.

A linguagem audiovisual se destaca por reunir componentes que envolvem os sentidos, nos aproximam de outras realidades e podem informar ao mesmo tempo em que entretém (MORÁN, 1995). Sua utilização pode estar relacionada a diversos objetivos, como, por exemplo, a sensibilização, a ilustração, ou a simulação de determinados conteúdos. No entanto, certas práticas devem ser evitadas, como o uso de vídeos sem muita conexão com a matéria ou mesmo sua exibição sem discussão (MORÁN, 1995; ROSA, 2000).

Para o ensino de Biologia Celular, o estagiário A utilizou o vídeo The inner life of the cell (2007), da BioVisions, que explora as estruturas que compõem uma célula e seu funcionamento. Esse vídeo foi apresentado antes da explicação dos conteúdos de membrana plasmática e organelas, com o intuito motivacional, e retomado após o estudo deles, para o detalhamento do vídeo e identificação das estruturas.

Para exemplificar o conteúdo Biotecnologia e trazê-lo mais próximo do cotidiano dos alunos, o estagiário D utilizou vídeos sobre organismos geneticamente modificados, disponíveis na Internet. Três vídeos foram exibidos, cada um com uma perspectiva distinta sobre os organismos geneticamente modificados. O primeiro deles era do IDEC (Instituto de Defesa 
do Consumidor), que explanava o que são esses organismos e quais suas possíveis ameaças ao consumidor brasileiro. O segundo era proveniente de uma rede televisiva, que explicava, com base em imagens, como esses organismos são produzidos e quais suas aplicações na agricultura. Por fim, o último vídeo exibido, de cunho mais radical, pertencia ao Greenpeace e mostrava os aspectos negativos desses organismos na saúde, na economia e na conservação da natureza.

Em ambas as situações os vídeos foram muito bem aceitos em sala e os estudantes participaram das discussões. Isso demonstra que a utilização de ferramentas que ajudem a ilustrar os conteúdos e o tragam para o dia a dia dos alunos, mostrando sua relevância com base em debates e questionamentos, é de suma importância para a consolidação do conhecimento, contribuindo para a formação do senso crítico dos estudantes.

Já em relação aos modelos didáticos, eles representam recursos que contribuem para melhor ilustrar e complementar conteúdos escritos e figuras planas presentes nos livros, principalmente quando esses são abstratos e microscópicos, como é caso de conteúdos de Biologia Celular e Molecular (ORLANDO et al., 2009).

Nesse contexto, o estagiário A construiu um modelo da bicamada lipídica utilizando materiais simples, como bolas de isopor, arame e velcro. Esse modelo contribuiu para complementar a explicação na aula sobre membrana plasmática e organelas.

Dentro do tema de Genética, o estagiário C montou um modelo com bolas de isopor pintadas que representavam as ervilhas de Mendel. No interior delas foi colocado o genótipo possível para aquela determinada característica. Com isso, os alunos puderam investigar a Primeira Lei de Mendel, fazendo correlações tanto fenotípicas como genotípicas.

Entretanto, dependendo do tema da aula, a confecção de materiais didáticos ou aulas práticas se torna uma tarefa complicada. Situação vivenciada pelo estagiário B, que utilizou de gravuras para a aula de Ciclos Biogeoquímicos, de modo que os alunos os entendessem de maneira mais visual e ajudassem a montá-los. Silva, Morais e Cunha (2011) afirmam que o quadro negro não consegue sozinho atingir os objetivos propostos pela disciplina de Biologia, já que esta necessita de ilustrações. Assim a utilização de gravuras pode ser uma solução quando a aula prática não é viável.

\section{Considerações finais}

A reflexão sobre a prática docente e sobre as relações que permeiam o ambiente escolar permite uma análise aprofundada do que é ser professor. Essa reflexão aliada ao estágio em docência acarreta, logo na formação inicial, a aproximação dos estudantes de licenciatura com a realidade escolar.

O uso da Matriz 3x3 proposto por Arruda, Lima e Passos (2011) se mostrou eficiente na identificação da percepção dos estagiários quanto a relação epistêmica, pessoal e social com o conteúdo, o ensino e a aprendizagem. Entretanto, a ambiguidade de algumas frases dificultou a aplicação desse instrumento, porém não impossibilitou a análise dos dados. Com efeito, no presente estudo foi possível verificar a partir das falas dos estagiários que as suas principais preocupações correspondem aos processos de ensino e aprendizagem, observando-se uma concentração das falas no segmento P-E na relação pessoal e no segmento E-S tanto na relação epistêmica como na pessoal. 
A aplicação de metodologias complementares teve o intuito de propiciar os processos de ensino e aprendizagem em sala de aula. A partir disso, os estagiários desenvolveram estratégias didáticas e pedagógicas considerando as necessidades observadas na vivência do cotidiano escolar.

De fato, a experiência da prática docente acompanhada pela reflexão dos aspectos a ela relacionada proporcionou uma ampla visão da complexidade da ação docente na escola. Diante disso, os estagiários poderão utilizar esse conhecimento e experiência no futuro exercício da profissão.

\section{Referências}

ALMEIDA, P. C. A.; BIAJONE, J. Saberes docentes e formação inicial de professores: implicações e desafios para as propostas de formação. Educação e Pesquisa, São Paulo, v. 33, n. 2, p. 281-295, 2007. Disponível em: < http://dx.doi.org/10.1590/S151797022007000200007>. Acesso em: 7 jun. 2016.

ARRUDA, S. M.; LIMA, J. P. C.; PASSOS, M. M. Um novo instrumento para a análise da ação do professor em sala de aula. Revista Brasileira de Pesquisa em Educação em Ciências, Belo Horizonte, v. 11, n. 2, p. 139-160, 2011. Disponível em: < http://revistas. if.usp.br/rbpec/article/viewFile/265/243>. Acesso em: 7 jun. 2016.

CARVALHO, M. A.; ARRUDA, S. M.; PASSOS, M. M. Análise das orientações dos supervisores em um subprojeto do PIBID na licenciatura em física. In: ENCONTRO NACIONAL DE PESQUISA EM EDUCAÇÃO EM CIÊNCIAS, 9., 2013, Águas de Lindóia. Atas... Rio de Janeiro: ABRAPEC, 2013. Disponível em: < http://www.nutes.ufrj. br/abrapec/ixenpec/atas/resumos/R1715-1.pdf>. Acesso em: 7 jun. 2016.

CHARLOT, B. Da relação com o saber: elementos para uma teoria. Porto Alegre: Artmed, 2000.

CHEVALLARD, Y. La transposición didáctica: del saber sabio al saber enseñado. Buenos Aires: Aique, 2005.

FEJOLO, T. B. A formação do professor de física no contexto do PIBID: os saberes e as relações. 2013. 95 f. Dissertação (Mestrado em Ensino de Ciências e Educação Matemática) - Universidade Estadual de Londrina, Londrina, 2013.

GIANOTTO, D. E. P.; DINIZ, R. E. S. Formação inicial de professores de biologia: a metodologia colaborativa mediada pelo computador e a aprendizagem para a docência.

Ciência \& Educação, Bauru, v. 16, n. 3, p. 631-648, 2010. Disponível em: < http:/ /dx.doi. org/10.1590/S1516-73132010000300009>. Acesso em: 7 jun. 2016.

INNER life of the cell, The. S.1.: BioVisions, 2007. Disponível em: < http://multimedia.mcb. harvard.edu/>. Acesso em: 7 jun. 2016.

LIMA, M. S. L. Reflexões sobre o estágio/prática de ensino na formação de professores.

Revista Diálogo Educacional, Curitiba, v. 8, n. 23, p. 195-205, 2008. Disponível em: <http:/ / www.redalyc.org/articulo.oa?id=189117303012>. Acesso em: 7 jun. 2016. 
Formação inicial docente e suas relações dentro do âmbito escolar ...

LÜDKE, M. Universidade, escola de educação básica e o problema do estágio na formação de professores. Formação Docente: revista brasileira de pesquisa sobre formação docente, Rio de Janeiro, v. 1, n. 1, p. 95-108, 2009. Disponível em: < http:/ formacaodocente. autenticaeditora.com.br/artigo/exibir/1/5/1>. Acesso em: 7 jun. 2016.

MAISTRO, V. I. A. Formação inicial, o estágio supervisionado segundo a visão de acadêmicos do curso de ciências biológicas. 2012. 126 f. Tese (Doutorado em Ensino de Ciências e Educação Matemática) - Universidade Estadual de Londrina. Londrina, 2012.

MARCELOS, V. A. Relações interpessoais: reflexões a cerca do cotidiano escolar. S.1.: Artigonal, 2009. Disponível em: < http://www.artigonal.com/educacao-artigos/relacoesinterpessoais-729010.html>. Acesso em: 7 jun. 2016.

MENEZES, N. C. R. Um olhar crítico-reflexivo sobre a práxis pedagógica compartilhada entre coordenação pedagógica e educação física numa escola aprendente. EFDeportes.com: revista digital, Buenos Aires, v. 17, n. 171, 2012. Disponível em: < http://www.efdeportes. com/efd171/um-olhar-cirtico-reflexivo-sobre-a-praxis-pedagogica.htm>. Acesso em: 10 dez. 2014.

MORÁN, J. M. O vídeo na sala de aula. Comunicação \& Educação, São Paulo, n. 2, p. 27-35, 1995. Disponível em: < http://dx.doi.org/10.11606/issn.2316-9125.v0i2p27-35>. Acesso em: 7 jun. 2016.

MORASSUTI, M. S. A. N. et al. Estágio supervisionado: observação, experimentação e reflexão. Multiciência, São Carlos, v. 9, p. 89-98, 2008. Disponível em: <http://www.unicep. edu.br/cenip/docs/revistamulticiencia/Multiciencia_vol9.pdf>. Acesso em: 7 jun. 2016.

ORLANDO, T. C. et al. Planejamento, montagem e aplicação de modelos didáticos para abordagem de biologia celular e molecular no ensino médio por graduandos de ciências biológicas. Revista Brasileira de Ensino de Bioquímica e Biologia Molecular, São Paulo, n. 1, p. A1-A17, 2009. Disponível em: < http:/ /www.educadores.diaadia.pr.gov.br/ arquivos/File/2010/artigos_teses/Biologia/Artigos/modelos_didaticos.pdf $>$. Acesso em: 7 jun. 2016.

PÉREZ GÓMEZ, A. O pensamento prático do professor: a formação do professor como profissional reflexivo. In: NÓVOA, A. (Coord.). Os professores e a sua formação. Lisboa: Dom Quixote, 1992. p. 92-114.

PERRENOUD, P. Formar professores em contextos sociais em mudança: prática reflexiva e participação crítica. Revista Brasileira de Educação, Rio de Janeiro, n. 12, p. 5-21, 1999. Disponível em: <http://www.unige.ch/fapse/SSE/teachers/perrenoud/php_main/ php_1999/1999_34.html>. Acesso em: 7 jun. 2016.

PIRATELO, M. V. M.; CARVALHO, M. A.; ARRUDA, S. M. Perspectivas de estagiários da licenciatura em física sobre a profissão docente: testando uma ferramenta de análise. In: SIMPÓSIO NACIONAL DE ENSINO DE CIÊNCIA E TECNOLOGIA, 3. 2012, Ponta Grossa. Anais... Disponível em: <http://www.sinect.com.br/2012/down. php?id=2627\&q=1>. Acesso em: 7 jun. 2016. 
ROSA, P. R. S. O uso dos recursos audiovisuais e o ensino de ciências. Caderno Brasileiro de Ensino de Física, Florianópolis, v. 17, n. 1, p. 33-49, 2000. Disponível em: < https:// periodicos.ufsc.br/index.php/fisica/article/view/6784/6249>. Acesso em: 7 jun. 2016.

ROSA, R. T. D.; VEIT, M. H. D. Estágio docente: análise de interações sociais em sala de aula. Educação \& Realidade, Porto Alegre, v. 36, n. 1, p. 295-316, 2011. Disponível em: $<$ http://seer.ufrgs.br/index.php/educacaoerealidade/article/view/10449/11576>. Acesso em: 7 jun. 2016.

SILVA, F. S. S.; MORAIS, L. J. O.; CUNHA, I. P. R. Dificuldades dos professores de biologia em ministrar aulas práticas em escolas públicas e privadas do município de Imperatriz (MA). Revista UNI, Imperatriz, v. 1, n. 1, p. 135-149, 2011. Disponível em: < http://www. unisulma.edu.br/Revista_UNI_artigo9_p135_149.pdf>. Acesso em: 7 jun. 2016.

SCHÖN, D. A. Formar professores como profissionais reflexivos. In: NÓVOA, A. (Coord.). Os professores e sua formação. Lisboa: Dom Quixote, 1992. p. 77-91.

SOUZA, A. R. et al. Gestão da escola pública. Caderno 2: planejamento e trabalho coletivo. Curitiba: UFPR, 2005. Disponível em: <http://www.gestaoescolar.diaadia.pr.gov. br/arquivos/File/sem_pedagogica/fev_2010/planejamento_trabalho_coletivo.pdf >. Acesso em: 7 jun. 2016. 